\title{
The Development of Early Childhood E-Port In The Implementation Of Authentic Assessment In Early Childhood Institutions
}

\author{
Leni Gonadi \\ State University of Malang, Semarang No.5 Street of Malang, \\ Indonesia
}

Corresponding e-mail : lenigonadi@gmail.com

\begin{abstract}
The present study aims at developing an early childhood e-port that benefits teachers to conduct authentic assessment in early childhood institutions. The study is in accordance with the implementation of information system assessment and authentic assessment of Curriculum 2013 of Early Childhood Education. The development of early childhood e-port in this study has adapted the research by Borg and Gall (2007) as well the elaborated design of developing e-port published by Barret (2000). The results of the study are presented as follows: the expert validation for pedagogical assessment shows $87.5 \%$ meaning that the assessment is qualified well and does not require any revision; the expert validation for information system design is under good qualification with $72.5 \%$; the expert validation for information technology also results well without any necessary revision in $82.5 \%$. According to the analysis of research data and the aforementioned improvement, it can be inferred that eport is valid and appropriate to be used to carry out authentic assessment in early childhood institutions.
\end{abstract}

Key words: early childhood e-port, authentic assessment

\section{INTRODUCTION}

Assessment of the process and result of early childhood education is in accordance with authentic assessment. Authentic assessment in Curriculum 2013 refers to "the sustainable assessment of learning process and output to determine the accomplishment of attitude (spiritual and social), knowledge, and skill competencies". The assessment does not only measure what a child knows, but rather to the emphasis of what a child can do.

Measuring is an early stage of reporting child's development to parents. The next stages following measuring are performing assessment and evaluation as mentioned by Basuki and Hariyanto, 2004 "the activity is performed in order, starting from measurement, assessment, evaluation, and report". The assessment of early childhood education is a key process to perceive a child's development.

Ministerial Regulation Number 146, 2014 on Curriculum 2013 of Early Childhood Education states "assessment is a process of collecting and processing information to measure a child's learning accomplishment". Teacher holds a prominent role in assessing the process and output of early childhood improvement. Teacher is required to have knowledge and comprehension about curriculum, early childhood competence, and characteristics of early childhood's stages of improvement.

The foundation of Curriculum 2013 (2014:8) states that the human resources required to answer the challenge of $21^{\text {st }}$ century are "those equipped with life and occupational skills, as well learning skills covering $4 \mathrm{C}$, namely critical thinking, communication, collaboration, creativity, and in addition to this is the skill to make use of technology, information, and media". Teacher of early childhood education is expected to keep up with the world changing and to own the criteria of the above mentioned human resource.

The era of technology as mentioned above brings about changes and development in various aspects of life, not to mention education. The huge interference of communication and information technology plays an essential role for education both as a support system and an educational media.

Haryanto, Ariani (2010: 172) states that the use of information technology encompasses three related activities, namely: (1) learning by utilizing information and communication technology, where educators and children together use ICT as a learning resource, tool and communication infrastructure, (2) electronic data processing, information management, management system and school works, (3) utilization of advanced information and communication technology in the hope that education services can be accessed easily and cheaply by the people in all regions of the country.

As a supplementary support of early childhood education system, especially in the implementation of authentic assessment with portfolio, information technology can be utilized to digitize portfolios carried out by early childhood educators. The use of a digital portfolio or so-called electronic portfolio (e-port) is expected to optimize the performance of authentic assessment of early childhood.

Kostelnik, Soderman dan Whiren (2007:183) in their book Developmentally Appropriate Curriculum Best Practices in Early Childhood Education suggest the early childhood educators as follows: "If you are working with children who are becoming skilled in using PowerPoint and other technology, and you have computers easily available, you may also want to consider implementation of 
digital or electronic portfolios, which are growing in popularity. Children's written work and drawings can be scanned into word processing files, and student performances of all kinds can be saved. In this way, instruction and assessment are easily combined as one".

Bhattacharya and Hartnett (2007) in their journals entitled E-port Assessment in Higher Education mentions "the importance of lifelong learning, the types of skill essential for lifelong learning, the value of providing evidence and reflection, and emphasis on activities outside formal education are all closely linked. The child's e-port assessment is concentrated on assessing the child's reflection on different artifacts and learning processes".

Caddy Mark (article volume 4: issue 1) in the publication of his article entitled The Electronic as Assessment Tool and More: The Drake University Model states "e-ports have advantages for both educators and children. They are easy to store, access, and share. Educators can listen to audio tasks over and over again, and many children are highly motivated to compose a portfolio because of the pleasure of choosing portfolio content ". The child is directly involved in the selection of the portfolio to be later inputted into the e-portfolio.

According to the previous discussion, the use of eports in the implementation of authentic assessment of early childhood education provides the chance for educators to access child's development outcomes through a more effective and well-recorded information system. Eports have now become an innovation of authentic assessment in early childhood education.

A good e-port has to meet the requirements of e-port. Barret (1998) in his publication entitled Feature Article Learning \& Leading with Technology (October, 1998) Strategic Questions What to Consider When Planning for Electronic Portfolios, describes e-ports should include the following elements: 1) learning objectives, 2) guideline to select materials (to store various collections), 3) task samples selected by educators and children, 4) educator's feedback, 5) pieces of self-reflection, 6) clear and appropriate criteria for evaluation (rubric by standard), and 7) standards and examples of good work.

The aforementioned elements have become a prominent factor in an e-port information system. The eligibility of e-ports in the assessment of early childhood education in related institutions embraces all requirements of an e-port information system in accordance with authentic assessment.

The result of field observation conducted by the researcher revealed that the portfolio is a pile of children's works collected into one volume but it does not deliver any meaning. The portfolio is merely a stack of children's works inserted into a specified folder or bound into a portfolio that is later distributed for each child. There has not been any explanation of what the works mean for the children. In this case, the implementation of authentic research has not been done well. The report has not clearly stated the outcomes of the child's development.

In the long term, this type of condition will likely to encourage educators to simply use information systems without prioritizing the feasibility of a technology-based assessment system. The performed authentic assessment only concerns on the children's achievement, so that educators feel the need to follow various innovations of assessment. E-port is one of the technology-based assessment innovations that can be used as an authentic assessment report.
According to her research, Gonadi (2016), states "there is a need for an information assessment system that really matches the characteristics of the authentic assessment of Curriculum 2013 on early childhood education".

The researcher is interested in conducting a study on the development of e-port information system in early childhood focusing on the implementation of authentic assessment. It is expected that the early childhood e-port can be used operationally and will become an innovative assessment tool in the implementation of early childhood's authentic assessment in early childhood institutions.

\section{REVIEW OF RELATED LITERATURE}

\subsection{E-port}

Cadd Mark (2009) in his publication entitled The Electronic Portfolio as Assessment Tool and More: The Drake University Model mentioned "e-port offers children and educators more benefits than any conventional means of assessment, including longitudinal traceable means of assessing progress. Technology allows early childhood educators to store the children's portfolios electronically (known as e-port)". E-port is a convenient way to keep children's portfolios and has many advantages over conventional assessments.

An expert of assessment, Joan Herman (1996, in Santrok, 2007) said that "assessment by portfolio has become more popular due to its natural way to integrate instructions and assessment". Portfolios can be collected on papers, photos and recordings, videos, or diskettes, computer hard drives, or CD-ROMs.

"Electronic portfolios or computer-based portfolios are utilized to describe the outcomes of portfolio stored in electronic format" (Hardy, 2001; Lankers, 1995 in Santrok, 2007). The records are in the form of texts, graphics, sounds, and videos. A computer-based portfolio will facilitate the transfer of information from educators to other educators or from school to school.

Furthermore, Barret (2000) in his publication Electronic Portfolios = Multimedia Development + Portfolio Development The Electronic Portfolio Development Process suggests "One of the most exciting developments in the school reform movement is the use of alternative forms of assessment to evaluate student learning, and one of the most popular forms of authentic assessment is the use of portfolios". Portfolio assessment becomes an appropriate alternative in the authentic assessment. Advanced technology and information should provide opportunities for many educational institutions to use e-port.

In addition to Barret (2000), he expresses his view of e-port development in early childhood education, "The point of the portfolio (electronic or paper) is to provide a "richer picture" of a student's abilities, and to show growth over time. Portfolios are being developed at all phases of the life span, beginning in early childhood, through $K-12$ and higher education, to professional teaching portfolios". The development of portfolio (electronics or papers) starts from early childhood education to higher education to enhance professional learning process. 
Based on the above discussion, it can be concluded that e-port is essentially a conventional assessment strategy that is presented in digital format and performed through information technology. E-port can be implemented in the authentic assessment of early childhood education. E-port has many advantages over conventional assessing methods, so it can be one of the information systems that has become a necessity in the implementation of authentic assessment in pedagogical institutions today.

\subsection{The Achievement of Early Childhood Development}

Regulation of the Minister of Education and Culture of the Republic of Indonesia Number 146, 2014 about the Curriculum 2013 on Early Childhood Education states "Indicators of child's development achievement are a specific and measurable marker to monitor/assess the child's growth at a certain age. The indicators function to monitor the development and not to be used directly as both teaching materials and learning activities". Educators design materials that can stimulate the outcomes of child's development.

\subsection{Authentic Assessment}

Regulation of the Minister of Education and Culture of the Republic of Indonesia Number 146, 2014 about Curriculum 2013 on Early Childhood Education Assessment Guidance mentions that authentic assessment is "an assessment of learning process and outcomes to determine the attainment of attitude competencies (spiritual and social), knowledge, and skills on an ongoing basis". Assessment does not only measure what the child knows, but rather emphasizes what the child can do.

Basuki and Hariyanto (2014: 168) suggested authentic assessment as "a form of assessment that requires the child to perform real-world tasks demonstrating their potential knowledge and skills". The implementation of real-world tasks in early childhood education includes the tasks of accomplishing core competencies of spiritual, social, skills, and knowledge applied in contextual learning activities.

Parkay (2011: 162) expressed "authentic assessment requires a child to solve a problem or to do the task as closely as possible to what the child is facing outside the classroom." Solving problems in early childhood education is included in the core competencies of knowledge and basic competencies of knowing how to solve daily problems and behave creatively.

Ronis (2011: 16-15) described "authentic assessment is the main form of alternative assessment". This assessment is considered authentic when it involves the child in a useful, important, and meaningful task. Authentic assessment is an assessment tool with a standard setting and not a standardized assessment tool. Implementing an assessment involving children on meaningful activities requires planning from educators. Assessment tools utilize a standard outcome of early child development.

Arifin (2009:180) stated "authentic assessment is an assessment technique used to determine the level of achievement of children's competence in the form of real ability, not something made-up or only obtained in the classroom". The fact can be seen in real everyday life in which learning activities reflect the real life actions.
Wortham (2005: 13) describes authentic assessment as follows: "Within this evolution in the purposes for assessment and interpretation of assessment is the move to authentic and performance assessment. Authentic assessment must have some connection to the real world; that is, they must have a meaningful context. They are contextual in that they emerge from the child's accomplishments". Authentic assessment must be closely related to real life, so it produces a really meaningful assessment. Authentic assessment is in accordance with the implementation of assessment in early childhood institutions.

According to some above definitions, authentic assessment of early childhood education is a meaningful assessment by which the educators continuously prioritize the process and outcomes according to the level of child's development accomplishment.

\section{METHODOLOGY}

\subsection{Research Design}

The development of present study adapts the research and development of Borg and Gall (2007) with design elaboration of e-port development published by Barret (2000). The stages of conducting the study on the development of early childhood e-port in the implementation of authentic assessment in early childhood institutions are as follows:

1. Identifying the aim of learning or outcomes / Defining the portfolio context and purpose.

The initial phase of the present study is to identify the aim of e-port information system on authentic assessment activities at early childhood institutions. The researcher identifies the needs, contexts, and objectives of why the development of early childhood e-port information system is needed. The results of field observation and scientific studies are: (1) there is a need of an assessment information system that is perfectly consistent with the characteristics of authentic assessment in Curriculum 2013 on early childhood education, (2) the implementation of the authentic assessment has not been well implemented, the assessment focusing on the outcome has not yet displayed the child's progress.

2. Analyzing the teaching activities to identify specific skills and procedures in achieving the teaching targets

The analysis on authentic assessment is carried out through observation, interview, and documentation. The result of the interview and observation is presented as follows: (1) the readiness to implement Curriculum 2013 on Early Childhood Education has been achieved, (2) the implementation of portfolio assessment is conventional that is performed by documenting the children's works in a portfolio book, the information system refers to the outcome of child's development based on the indicators marked by some codes called 
levels. The documentations show the use of information system that has been so far used in the form of indicator reports with achievement codes, namely E (Excellent), VG (Very Good), $G$ (Good), $S$ (Satisfactory), and NI (Need Improvement).

3. Identifying the learners' skills and attitudes, the characteristics of teaching, knowledge, and skills that they are going to perform

The analysis on learners' skills and attitudes is carried out by interview with educators and observations to find out the core competencies, basic competencies, and growth achievement for children of 4-6 years old.

4. Analyzing teaching needs and objectives into the implementation of specific targets

The need analysis of authentic assessment is performed by observation and interview with the principles of kindergarten and educators of early childhood education. Based on the analysis on questionnaires, the ability of the educators to operate technological devices supports the use of information system in learning activities and assessment for early childhood

5. Developing instruments that correspond directly to the knowledge and skills expected to be achieved/Applying e-port

The analysis of assessment instruments of core competencies, basic competencies, and growth achievement of children utilizes a rating scale and a rubric of 4,3,2,1. The educators insert the description of child's development based on the rating scale and rubric selected as an outcome of assessing the improvement.

6. Enhancing the strategies to perform the objectives/Checking the e-port comprehensiveness

At this stage, the researcher develops an implementation strategy. According to the data analysis of interview, observation, and documentation, as well to the related theory and concept of e-port development, the initial draft of e-port improvement encompasses the data of the educators, children, core competencies, basic competencies, and the child's achievement at the age of 4-6 as arranged in Curriculum 2013.

\section{E-port Development/Connecting e-port}

The hardware utilized in the development of early childhood e-port is shown as follows:

Table 1. Hardware for early childhood E-port

\begin{tabular}{|l|l|}
\hline $\begin{array}{l}\text { Tools to } \\
\text { operate } \\
\text { e-port }\end{array}$ & $\begin{array}{l}\text { Tools to take and store children's } \\
\text { works and activities for a temporary } \\
\text { use }\end{array}$ \\
\hline Computer & Video recorder \\
\hline Scanner & Digital Camera \\
\hline & Voice recorder (MP3 Player) \\
\hline & CD Room \\
\hline
\end{tabular}

The softwares used in developing e-port are those supporting a production of web-based application program, that are: a. windows as an operating system

b. apache as a web server.

c. php mysql as a database

d. macromedia dreamweaver as a layout and writing editor

e. file-file php html as well data operating applications used to design a picture, such as photoshop.

8. Formative Evaluation/ E-port Presentation The present study and development examines a product of information system of early childhood e-port to be implemented as a portfolio assessment for early childhood in related institutions. Formative evaluation of early childhood e-port is obtained from the results of expert validation and appropriateness of the trial results on educational evaluation, the expert of information system design, the expert of information technology, and trials for each one of the two educators.

\section{METHOD OF DATA COLLECTION AND RESEARCH INSTRUMENTS}

The method of data collection in the development of early childhood e-port in the implementation of authentic assessment in early childhood institutions is by conducting interview and questionnaires. The research instrument is used to measure the research variables in the development of early childhood e-port in implementing the authentic assessment in early childhood institutions. The instrument used is the rating scale. The testing of instrument construct validity used in this research is carried out by referring to the experts' judgments.

\subsection{Technique of Data Analysis}

The present study employs descriptive statistic data analysis and inferential data analysis.

1.Descriptive Statistic Data Analysis

The technique of descriptive statistic data analysis is used to organize the data obtained from the questionnaires in the form of descriptive percentages. The result of percentage accumulation is used to make a decision whether the e-port needs revision. The formula used to calculate the percentage is:

$$
\begin{aligned}
& \text { Per item data formula } \\
& P=\frac{Z}{x i} \times 100 \%
\end{aligned}
$$

Note :

$\mathrm{P}$ : Percentage

$\mathrm{x}$ : The respondent's answer in an item

$x i$ : The total ideal score in an item

$100 \%$ : Constants

(Sugiyono, 2014: 138)

The scoring scale used in the questionnaires is: 
Table 2. Conversion of Achievement Level

\begin{tabular}{|l|l|l|}
\hline $\begin{array}{l}\text { Achievement } \\
\text { Level }\end{array}$ & Qualifications & Note \\
\hline $86 \%-100 \%$ & Excellent & No revision \\
\hline $71 \%-85 \%$ & Well & No revision \\
\hline $56 \%-70 \%$ & Fair & Need revision \\
\hline $41 \%-55 \%$ & Less fair & Need revision \\
\hline $0 \%-40 \%$ & Poor & Need revision \\
\hline
\end{tabular}

(Adapted from Kuswandi in Praherdiono 2009: 83).

Kuswandi in Praherdiono (2009:84) states "Cumulatively, when the result achieves $71 \%$ above, it means that the developed product is considered to own a satisfied/positive validity score and is reasonable to use". So, the result can be used in the implementation of authentic assessment in early childhood institutions.

\section{RESULTS AND DISCUSSION}

\subsection{The Output of Developing E- port/The Progress of Early Childhood Development}

Based on the research and development of e-port information system, the data shows a validity and feasibility of the trial results by the experts of education, information system design, information technology, and one-on-one testing on two educators. The results of a questionnaire that have been reviewed by the education experts stated that the e-port information system of early childhood shows the value of $87.5 \%$ which means there is in a very good qualification and does not need to be revised. The questionnaire results from the experts of eport system design is $72.5 \%$ which also means good in qualification. The questionnaire results from the experts of information technology is as much $82.5 \%$ meaning that it is under good qualification and does not need to be revised.

The results obtained from the expert validation indicate that early childhood e-port meets the expected level of the e-port development. Barrett (2000) in Electronic Portfolios = Multimedia Development + Portfolio Development The Electronic Portfolio Development Process described that in reviewing the electronic portfolio, it is important to set different levels of expectations for its development. The level of expectation has a valid qualification and is feasible to use, that is with percentage above $71 \%-85 \%$.

Cadd Mark (2009) in his publication entitled The Electronic Portfolio as Assessment Tool and More: The Drake University Model mentioned "e-ports offer children and educators more benefits than any conventional means of assessment, including the longitudinal traceable means of progress. Technology allows early childhood educators to keep children's portfolios electronically (known as eports) ". E-port is a convenient way to store children's portfolios, and it has many advantages over conventional assessments.

\section{CONCLUSION AND RECOMMENDATIONS}

\subsection{Conclusion}

\section{Early Childhood $E$-port}

Based on the results of the research, it can be inferred that there has been a product of information system called early childhood e-port that is implemented in authentic assessment in early childhood institutions, especially in Playgroup and Kindergarten Raudhatul Jannah Sidoarjo.

The research and development of early childhood eport adapts the previous study conducted by Borg and Gall (2007) and the elaborated design of developing e-port published by Barret (2000). The product is an information system called early childhood e-port and a guidebook to use the e-portfolio for the development of early childhood education.

Early childhood e-port functions to record, store, describe, and display the process and outcomes of the children's achievement in a digital form. The user's guidebook presents the procedures to perform a complete e-portfolio information system on early childhood development.

\section{RECOMMENDATIONS}

The recommendations of the study are classified into three sections that are recommendations to use, recommendations to disseminate, and recommendations for the future researchers.

1. Recommendations to use

a. The information system of early childhood e-port is suggested to be applied in early childhood institutions to carry out the authentic assessment.

b. The guidebook of information system of early childhood e-port is meaningful to read before use.

2. Recommendations to disseminate

To answer the challenge of the $21^{\text {st }}$ century, the educators are expected to improve their competencies along with the world's changes. In this case, early childhood e-port can be one innovation to perform authentic assessment in technology-based early childhood institutions.

3. Recommendations for the future researchers

The present study is expected to be a literature and directive for the future studies related to the innovation of conducting authentic assessment in early childhood institutions.

\section{Implications of the Result of the Study}

Performing the information system of early childhood e-port requires technical and operational readiness from the early childhood institutions and the available educators. The early childhood educators need to prepare a set of computer with a scanner to allow the institutions use the internet connection at ease. The educators as the e-port user are expected to be able to utilize technological devices to record the process and outcome of children's works digitally, and to input the records into the early childhood e-port. 


\section{REFERENCES}

[1] Ariani, Niken \& Haryanto, Dany. (2010). Pembelajaran Multi Media Di Sekolah. Jakarta : PT Prestasi Pustakarya.

[2] Arifin, Zainal. (2009). Evaluasi Pembelajaran. Bandung : PT Remaja Rosdakarya

[3] Basuki. Ismet \& Hariyanto. (2014). Asesmen Pembelajaran. Bandung: PT. Remaja Rosdakarya

[4] Barret. C.Hellen. (1998). "Feature Article Learning \& Leading with Technology (October, 1998) Strategic Questions What to Consider When Planning for Electronic Portfolios". Diakses melalui http://electronicportfolios.com/handouts/question s(Oct98).pdf pada tanggal 6 November 2014

[5] Barret. C. Hellan. (2000). "HOW TO Create Your Own Electronic Portfolio based on the "5-by-5 Model" of Electronic Portfolio Development". Diakses melalui http://transition.alaska. edu/www/ portfolios.html pada tanggal 6 November 2014

[6] Bhattacharya.M dan Hartnett. M, (2000). "Penilaian E-portofolio di Perguruan Tinggi. Massey University, Selandia Baru “. Diakses melalui M.Bhattacharya@massey.ac.nz pada tanggal 9 November 2014

[7] Borg. R. Walter dan Gall. D. Meredith. (2007). "Educational Research An Introduction Eight Edition”. United State. Pearson Education, Inc.

[8] Cadd. Mark. (2004). "The Electronic Portfolio as Assessment Tool and More: The Drake University Model". Article Drake University Volume: 42 Issue: 1 Diakses melalui http://www.iallt.org/iallt_journal/the_electronic_p ortfolio as assessment tool and more the drak e_university_model pada tanggal 9 November 2014

[9] Departemen Pendidikan Nasional. 2003. UndangUndang Sistem Pendidikan Nasional (UU RI No.20 Tahun 2003) dan Peraturan Pelaksanaannya. Jakarta: Departemen Pendidikan Nasional.

[10]Departemen Pendidikan Nasional (2005), Undang-undang No. 14 tahun 2004 tentang Guru dan Dosen, Jakarta: Depdiknas
[11]Electronic Portfolio. 2008. Diakses melalui http://en.wikipedia.org/wiki/Electronic_portflo pada tanggal 9 November 2014

[12] Kementrian Pendidikan dan Kebudayaan UNESA. 2012. Pedoman Penulisan Tesis dan Disertasi. Surabaya: UNESA

[13] Kostelnik dkk. (2007). Developmentally Appropriate Curriculum Best Practises in Early Childhood Education. New Jersey: Pearson

[14] Kuswandi, Dedi. (2001). Validasi Media: analisis kelayakan media yang akan dikembangkan. Bahan kuliah tidak diterbitkan. Malang: jurusan TEP FIP UM.

[15] Nazir. Moh. (2003). Metode Penelitian. Jakarta. Ghalia Indonesia

[16] Parkay. W. Forrest. (2011). Menjadi Seorang Guru. Jakarta: Indeks

[17]Penilaian Autentik. 2009. Diakses melalui http://id.wikipedia.org/wiki/Penilaian_Autentik pada tanggal 6 November 2014

[18] Peraturan Menteri Pendidikan Nasional Republik Indonesia Nomor 16 Tahun 2007 tentang Standar Kualifikasi Akademik dan Kompetensi Guru.

[19] Peraturan Menteri Pendidikan dan Kebudayaan Republik Indonesia Nomor 146 Tahun 2014 tentang Kurikulum 2013 Pendidikan Anak Usia Dini.

[20] Ronis, Diane. (2011). Asesmen Sesuai Cara Kerja Otak. Jakarta: Indeks

[21] Santrock. John. W. (2007). Psikologi Pendidikan. Jakarta: Kencana Prenada Media Group.

[22] Sarwono, Jonathan. (2006). Panduan Ceapat dan Mudah SPSS 14. Jogyakarta: Andi Jogyakarta.

[23] Sudijono, Anas. (2009). Pengantar Statistik Pendidikan. Jakarta: PT. Raja Grafindo Persada.

[24] Sugiono. (2014). Metode Penelitian Pendidikan Kombinasi (Mixed Methods). Bandung: Alfabeta.

[25] Sugiono. (2014). Metode Penelitian Pendidikan Kombinasi (Mixed Methods). Bandung: Alfabeta.

[26] Venn, J. J. (2000). Assessing students with special needs (2nd ed.). Upper Saddle River,NJ: Merrill. http://www.unm.edu/ devalenz/handouts/portfoli o.html pada tanggal 6 November 2014.

[27] Wikipedia.2008.electronicportfolio .http://en.wikipedia.org/wiki/Electronic_portfolio pada tanggal 6 November 2014

[28] Wortham. (2005). Assessment in Early Childhood Education. New Jersey: Pearson 